\title{
Charcot-Böttcher 類結晶の組織化学的、電顕的研究
}

\author{
中 里洋一, 小川晃, 瓦井美津江 \\ 群馬大学医学部第一病理学教室（主任：石田陽一教授） \\ (昭和57年 6 月 29 日 受付)
}

\section{はじめに}

ヒト辠丸精細管の Sertoli 細胞には1896年、Lubarsch $^{1)}$ にようて最初に記載され Charcot-Böttcher 類結晶と命名された結晶状構造物が存在する。 この類結晶の形態に関しては多くの研究がなさ れ²、電顕的には平行に走る細線維が束を成した構 造を示すことが明らかにされてきだ) 5).しかしそ の化学的性質、機能についてはいまだ解明されてい ない6).

我々は睪丸腫瘍の剖検例で健側の睪丸に多数の Charcot-Böttcher 類結晶の出現した症例を経験し た。この症例の概略を述べると共に Charcot-Böttcher 類結晶について組織化学的、電顕的検索を行つ たので報告する。

\section{検索症例と方法}

症例は24才男性。右睪丸腫瘤、下腹部痛で発症し 某医にて右除睪術をうけた。病理組織学的に悪性腫 瘍（胎児性癌および精上皮腫）と診断され、某病院 に転院後化学療法と放射線照射を施行された。汎血 球減少症、腎機能障害をきたし、初発後 1 年 1 カ月 の経過で死亡した。剖検すると右腎、肝、左右肺、 右副腎、膵、大脳、リンパ節などに腫崵転移巣が認 められ、それらは病理組織学的には䄉毛上皮癌の部 分像を伴う胎児性癌であった。

本症例の左睪丸を検索材料とした。剖検時摘出さ れた睪丸は $10 \%$ 燐酸緩衝 formalin にて固定し、通 常の方法で paraffin 切片を作製し光顕的および組 織化学的検索を行った。検索には hematoxylin-eosin, Mallory's anilin blue, periodic acid Schiff, phosphotungstic acid hematoxylin, toluidine blue ( $\mathrm{pH}$ 7.0), Alcian blue ( $\mathrm{pH}$ 2.5), Ziehl-Neelsen, Berlin blue, luxol fast blue, Nile blue, Sudan black B, coupled tetrazonium, Coomassie brilliant blue, Feulgen, methylgreen-pyronin の各染色法を
用い，また無染色標本について重屈折性と自家螢光 の有無を検索した。

Formalin 固定組織より電顕用の小片を切り出 し、 $2 \%$ オスミウム酸 $(0.05 \mathrm{M}$ 燐酸緩衝液、 $\mathrm{pH} 7$. 4)にて後固定、エ夕ノール脱水を経てエポキシ樹脂 （Quetol 812）に包埋した。LKB Ultrotome IIIで 薄切し、ウラン・鉛二重染色を施して、日本電子 7 A，100C 型電子顕微鏡で 観察した。

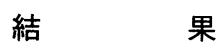

病理組織学的所見 精細管上皮には強い萎縮があ り、精子系細胞はほとんど完全に消失している（図 1). Sertoli 細胞の形態抒よび数は比較的良く保た れている。精細管の固有膜は肥厚し所々で内腔側に 向って波打っている。間質は線維性ないし硝子様で 広い。間細胞には lipofuscin 顆粒の増量が認められ る。睪丸内には腫瘍浸潤は認められない。

Sertoli 細胞は類円形の核と淡明な細胞質を持ち, 細胞間の境界は不鮮明である。細胞の基底側より核 近傍にかけて好酸性針状の Charcot-Böttcher 類結 晶が認められる(図 2)。類結晶は一つの精細管の断 面内に20-40個出現しており, 高倍率での観察により 容易に認識し得る. 類結晶は長さ $5-13 \mu$, 巾 $0.5-1$ $\mu$ の針状で両端は尖鋭である。その長軸は概ね細胞 の長軸に並行している. 類結晶の内腔側の先端は核 のレベル程度の所にとどまっており, 内腔近くまで 達することは稀である。

組織化学的所見 Formalin 固定組織の paraffin 切片にて Charcot-Böttcher 類結晶の染色性を検索 した（表 1)。類結晶は hematoxylin-eosin 染色で は eosinophilic で, Mallory’s anilin blue では赤色 に染まる. Phosphotungustic acid hematoxylin に 陽性であるが、自家螢光㧍よび重屈折性は認められ ない．蛋白質反応である coupled tetrazonium 法お よび Coomassie brilliant blue 染色に陽性である が, 糖質, 脂質, 核酸の反応はいずれも陰性である. 


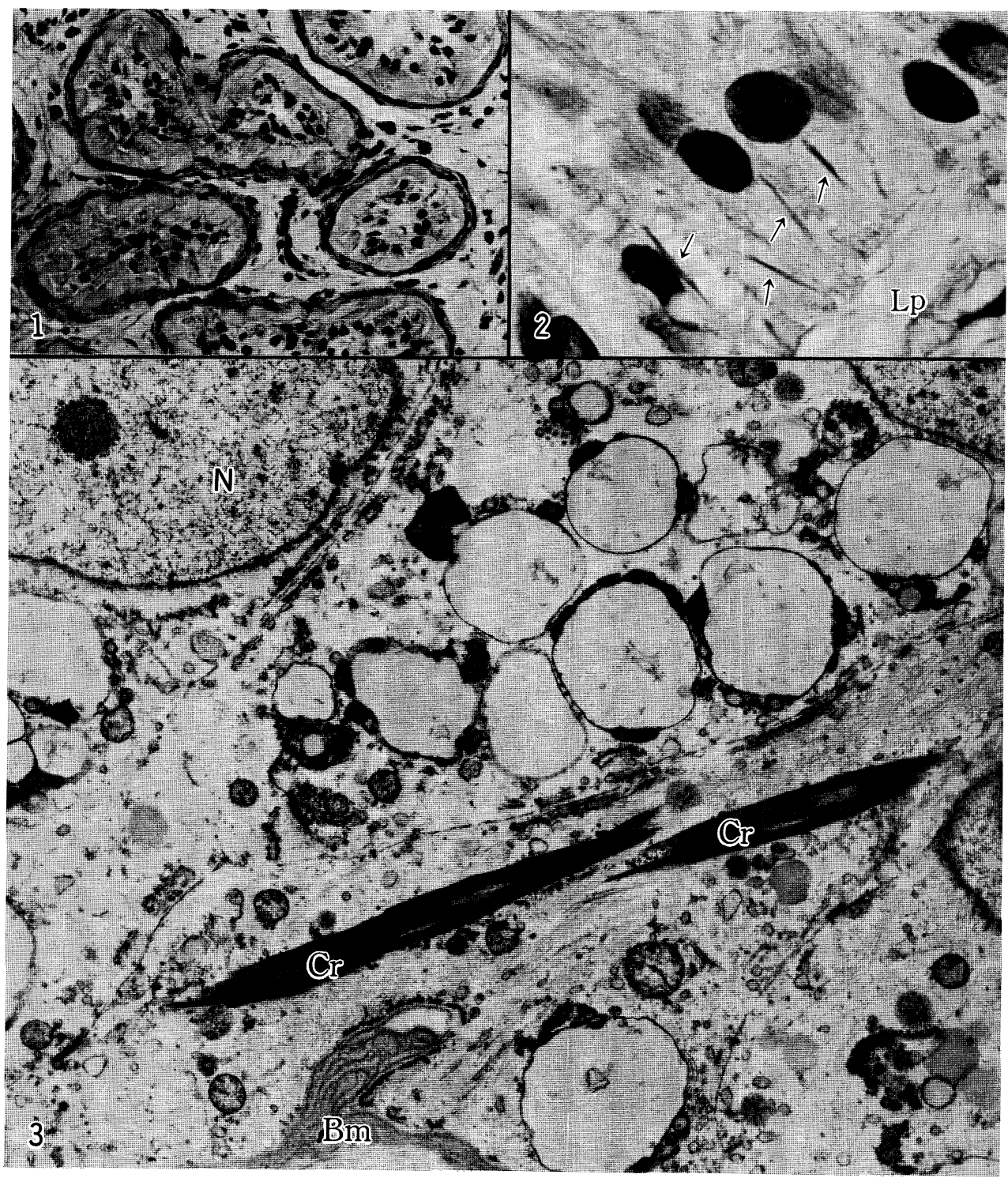

図 1 精細管は萎縮性で固有膜が肥厚している.H. E. 染色, 190倍

図 2 Sertoli 細胞の基底側に Charcot-Böttcher 類結晶（矢印）が認められる. Lp：固有膜，H. E. 染色, 1,120 倍.

図 3 Charcot-Böttcher 類結晶 $(\mathrm{Cr})$ の弱拡大像. $\mathrm{N}$ ： Sertoli 細胞の核， Bm：基底膜，7,700倍. 
Charcot-Böttcher 類結晶

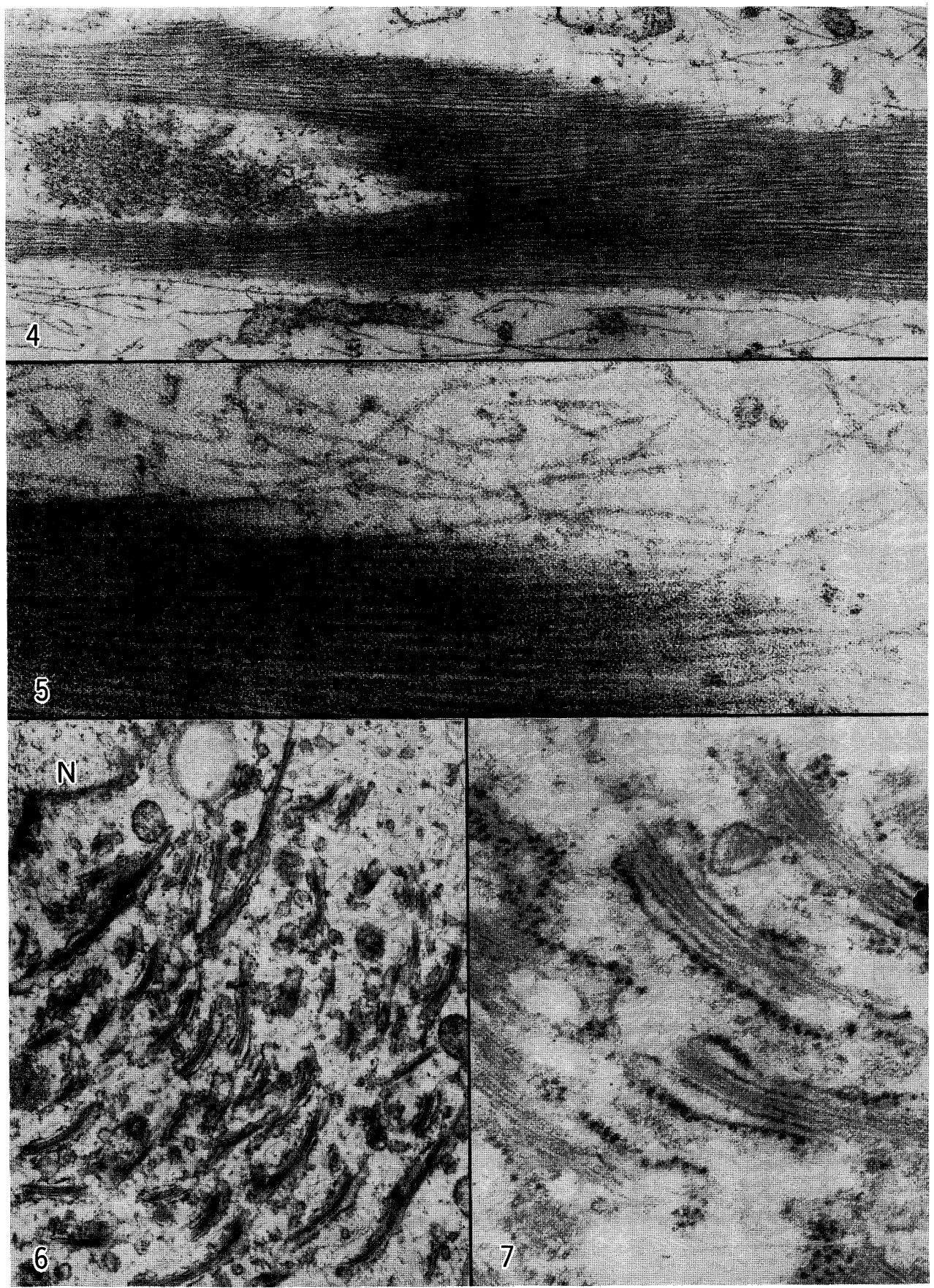

図4Charcot-Böttcher 類結晶は細線維束より構成されており, 内部に顆粒状物質を容れている。 53,800 倍

図 5 類結晶細線維と細胞質線維との間に連続性がみられる。115,000倍。

図 6 粗面小胞体と細線維束より成る構造物が核近傍に集簇している. 14,200倍.

図7 図 6 の強拡大. 50,700 倍. 
表 1 Charcot-Böttcher類結晶の組織化学

\begin{tabular}{lc}
\hline \multicolumn{1}{c}{ 染色 法 } & 結 \\
\hline Hematoxylin-eosin \\
Mallory's anilin blue & eosinophilic \\
Phosphotungustic acid hemato- & + \\
xylin & red \\
Birefringence & - \\
Autofluorescence & - \\
Berlin blue & - \\
Periodic acid Schiff & - \\
Toluidine blue (pH 7.0$)$ & - \\
Alcian blue (pH 2.5) & - \\
Luxol fast blue & - \\
Nile blue & - \\
Sudan black B & - \\
Ziehl-Neelsen & - \\
Coupled tetrazonium & + \\
Coomassie brilliant blue & + \\
Feulgen & - \\
Methylgreen-pyronin & - \\
\hline
\end{tabular}

電子顕微鏡的所見 Sertoli 細胞は類円形の核と 広い細胞質を持っている。核膜は平滑であるが浅い 陷凹を示すこともある.クロマチン顆粒は核内に均 等に分布している. $1 \sim 2$ 個の小型の核小体を含ん でいる。細胞質内には mitochondria，粗面および 滑面小胞体, 脂肪滴, lipofuscin などの小器官と直 径 $10 \mathrm{~nm}$ の細線維が認められる. Annulate lamellae を含む細胞もある.

Charcot-Böttcher 類結晶は直径 9-11 nmの直線 的かつ平行に走る細線維が密に集積して構成されて おり，周囲に限界膜は認められない(図 3,4)。細 線維束はときに分岐しあるいは融合し, 細胞質小器 官や電子密度の高い顆粒をその内部に補捉してい る. 類結晶の辺緑部では細線維の「毛羽立ち」がみ られ, 構成細線維と細胞質細線維との連続性が観察 される(図 5 )。一部の細胞では数本ないし十数本の 細線維束の両側に粗面小胞体が密接した特異な構造 が観察される(図 6)。この細線維束は CharcotBöttcher 類結晶の構成細線維によく似た構造を示 している。この様な構造物は核の近傍に多数集合し て出現する傾向がある. 粗面小胞体の外側面には直 径約 $26 \mathrm{~nm}$ の ribosome 顆粒が並んでいるが、細線 維束に接する内側面には顆粒がみられない（図 7 )。
また，細線維束に沿って ribosome 顆粒のみが配列 する像もみられることがある。

$$
\text { 考案 }
$$

Charcot-Böttcher 類結晶は1896年 Lubarsch ${ }^{1)}$ に よって最初に記載されたヒト睪丸 Sertoli 細胞の特 異な構造物である。この構造物は性成熟期のヒトに のみ見出され5), 思春期以前や老人には認められな い. ヒト以外ではブ夕77,8)とコアラ9の Sertoli 細胞 に近似の類結晶が記載されているが、それらとヒト の Charcot-Böttcher 類結晶との間にはいくつかの 相違点もあり, 同一とは見なし難い. Charcot-Böttcher 類結晶の化学的性質, 機能は現在のところ不明 である ${ }^{6)}$. Charcot-Böttcher 類結晶の化学的組成に ついて Sohval ら ${ }^{5)}$ はその形態学的特徵より蛋白質 から成る構造物と推測している。 また Toyama ら ${ }^{81}$ は heavy meromyosin との結合性の欠如より，構成 細線維はブ夕の類結晶の細線維と異なり actin-like ではないと結論している． Charcot-Böttcher 類結 晶の組織化学的研究はきわめて乏しく, わずかに Lubarsch $^{1)}$ が沸騰水および50\%酢酸に溶解するが アルカリ液には溶けないと述べているにすぎない。 これは一つには類結晶の出現頻度が低く, また出現 していてもきわめて小型で通常の光顕的観察では見 落されやすいためと思われる，今回我々が検索した 症例では多数の類結晶が, ほとんどすべての精細管 に出現していたため, 組織化学的検索が可能となっ た。類結晶は蛋白質染色に陽性所見を示したが, 糖 質，脂質，核酸の染色はいずれも陰性であった。蛋 白質を主成分とする構造物と考えられる。

Charcot-Böttcher 類結晶の超微像に関しては多 くの報告がなされている ${ }^{3) \sim 5)}$.この構造物は結晶の 軸と平行に走る細線維ないし細管の束から成り，そ れら細線維（細管）の直径は $150 \AA{ }^{4)}, 50-150 \AA$ (130$180 \AA)^{5)}$ と記載されている. 細線維束は時に枝分れ, 融合を示し, 類結晶内に lacunae を作り，そこに顆 粒状，線維状物質を容れている。類結晶を構成する 細線維と細胞質内細線維との間に連続性が観察され ることもある(4),5). 今回我々の検索した症例の類結晶 も上記とほぼ同様の所見を示していた。類結晶は直 径 9-11 nm の直線的な細線維の束より構成されて おり,これら構成線維と細胞質内の直径 $10 \mathrm{~nm}$ 細線 維との間には連続性が認められた。細管構造は観察 されなかった。細胞質内に出現する直径 $10 \mathrm{~nm}$ 前後 
の細線維は総括的に intermediate filament と呼ば れており, cytoskeleton として細胞の形態保持の役 割をはたしている ${ }^{10)}$. Intermediate filament を構成 する蛋白質は現在までに 5 種類（ neurofilament protein, glial fibrillary acidic protein, vimentin, prekeratin, desmin ) 知られており, 細胞の種類に よって線維構成蛋白が異なっている ${ }^{10)}$ 。すなうち neurofilament protein は神経細胞, glial fibrillary acidic protein は神経膠細胞に特異的であり, desmin は主に筋細胞, prekeratin は主に上皮性細胞に 存在している。一方, vimentin は主に間葉系細胞 に認められるが神経膠細胞や上皮性細胞にも存在す ると言われている。 Sertoli 細胞のintermediate filament がいかなる構成蛋白を持つか明らかでは ないが， Charcot-Böttcher 類結晶の構成線維が Sertoli 細胞の intermediate filament と密接な関係 にある点より intermediate filament 構成蛋白質の 側面から Charcot-Böttcher 類細晶の化学的性質が 明らかにされ得ると期待される。

Charcot-Böttcher 類結晶の形成過程についても 不明な点が多い. Bawa $^{3)}$ は不規則に分布している longitudinal filament が集合し平行に配列して類結 晶になると推測している. 我々の検索では一対の粗 面小胞体が平行に配列し, 両者の間に十数本の細線 維が束を成して認められる像が観察された。この細 線維束は Charcot-Böttcher 類結晶の構成々分とよ く類似しており，同類結晶の subunit と見做しても 不自然ではない. 粗面小胞体で合成された線維蛋白 が一対の cisternae の間で平行に走る細線維束を形 成し,これらの subunit がさらに selfassembly を 重ねる過程で Charcot-Böttcher 類結晶を構成する と推測される。

Charcot-Böttcher 類結晶の機能について Sohval ら5)は本構造物が性成熟期にのみ観察される点より 精子形成過程に関係していると推論している。しか し Chemes ら ${ }^{11)}$ は肧細胞無形成㧍よび高度の胚細 胞減少を示す患者に, de Kretser ${ }^{12)}$ は hypogonadotrophic hypogonadism の症例で, また Livniら ${ }^{13)} は$ 無精子症患者に扔いて Sertoli 細胞の CharcotBöttcher 類結晶を観察している. 我々の症例も抗癌 剂投与に起因する高度の胚細胞減少例であるが, 多 数の類結晶が観察された. 類結晶の出現と精子形成 過程との間の因果関係を示唆する証拠は現在のとこ ろ不十分と言うべきであろう。

\section{ま と め}

睪丸 Sertoli 細胞内に多数の Charcot-Böttcher 類結晶の出現した症例を報告し, 類結晶を組織化学 的, 電顕的に検索した。類結晶は組織化学的には蛋 白質反応が陽性で, 脂質, 糖質, 核酸などは検出さ れなかった。電顕的には平行に走る直径 9-11nm の 細線維束により構成されており,その細線維と細胞 質の intermediate filament との連続性が認められ た。一部の細胞には細線維束と一対の粗面小胞体よ り成る特異な構造物が観察された。

\section{謝辞}

御指導,御校閲をいただきました石田陽一教授, 組織標 本の作製, 組織化学的検索に御協力いただきました山崎 博子文部技官に深謝いたします。

\section{文献}

1) Lubarsch, O.: Ueber das Vorkommen krystallinischer und krystalloider Bildungen in den Zellen des menschlichen Hodens. Virchows Arch. Pathol. Anat., 145 : 316-338, 1896.

2) Stieve, H. : Harn-und Geschlechtsapparat, in "Handbuch der Mikroscopischen Anatomie des Menschen", ed. by Möllendorff, W. v., Bd. 7, Teil 2, Springer, Berlin, 1930, pp, 119126.

3) Bawa, S. R. : Fine structure of the Sertoli cell of the human testis. J. Ultrastr. Res., 9: 459-474, 1963.

4) Nagano, T. : Some observation on the fine structure of the Sertoli cell in the human testis. Z. Zellforsch., 73:89-106, 1966.

5) Sohval, A.R., Suzuki, Y., Gabrilove, J.L. and Churg, J. : Ultrastructure of crystalloids in spermatogonia and Sertoli cells of normal human testis. J.Ultrastr. Res., 34:83-102, 1971.

6) Bloom, W. and Fawcett, D.W.: A Textbook of Histology, 10th ed., W.B. Saunders, Philadelphia, London, 1975.

7) Toyama, Y.: Ultrastructural study of crystalloids in Sertoli cells of the normal, intersex and experimental cryptorchid swine. Cell Tiss. Res., 158:205-213, 1975. 
8) Toyama, Y., Obinata, T. and Holtzer, H. : Crystalloids of actin-like filaments in the Sertoli cell of the swine testis. Anat. Rec., 195: 47-62, 1979.

9) Harding, H.R., Carrick, F.N. and Shorey, C. D. : Crystalloid inclusions in the Sertoli cell of the koala, Phascolarctos cinereus ( Marsupialia ) . Cell Tiss. Res., 221:633-642, 1982.

10) Lazarides, E. : Intermediate filaments as mechanical integrators of cellular space. Nature, 283:249-256, 1980.

11) Chemes, H.E., Dym, M., Fawcett, D.W., Javadpour, N. and Sherins, R.J. : Patho-physio- logical observations of Sertoli cells in patients with germinal aplasia or severe germ cell depletion. Ultrastructural findings and hormone levels. Biol. Reprod., 17:108-123, 1977.

12) De Kretser, D.M. : The fine structure of the immature human testis in hypogonadotropic hypogonadism. Virchows Arch. Abt. B Zellpath., 1:283-296, 1968.

13) Livni, N., Palti, Z., Segal, S. and Laufer, A. : Fine structure of Sertoli and Leydig cells in azoospermic human testis. Arch. Pathol. Lab. Med., 101:442-445, 1977.

\section{HISTOCHEMICAL AND ELECTRON MICROSCOPIC STUDIES OF CHARCOT-BÖTTCHER CRYSTALLOIDS IN HUMAN SERTOLI CELLS YOICHI NAKAZATO, AKIRA OGAWA AND MITSUE KAWARAI}

First Department of Pathology, Gunma University School of Medicine, Maebashi, Japan

(Director : Prof. YOICHI ISHIDA)

A large number of Charcot-Böttcher crystalloids were observed in tesicular Sertoli cells of a 24 year-old man. The crystalloids were stained positively with coupled tetrazonium method and with Coomassie brilliant blue. However, histochemical methods for lipids, polysaccarides and nucleic acids failed to stain the structure. The crystalloids consisted of closely packed Parallel arreys of dense filaments 9-11 nm wide. These filaments were frequently continuous with cytoplanmic intermediate filaments. An association of filamentous elements and a pair of rough endoplasmic reticulum was occasionally found in perikaryal cytoplasm of the Sertoli cells. It is suggested that the crystalloids are proteinaceous in nature and are formed by the aggregation of intermediate filaments.

Key words: Sertoli cell, Crystalloid, Intermediate filament, Histochemistry, Electron microscopy. 